\title{
Sciendo
}

DOI: $10.2478 /$ jolace-2020-0014

\section{The perspectives of parents in relation to the concepts of the quality of pre-school education. Analysis of research discourse}

\author{
Jana Majerčíková \& Beata Horníčková \\ Tomas Bata University, Czech Republic \\ majercikova@utb.cz
}

\begin{abstract}
This theoretical study analyses interpretation of quality in pre-school education with regard to the position of the children's parents. This text is supported by research papers, mostly from the last two decades, and is based on three main sub-topics. The importance and benefits of systematic pre-school education for the child and the economic development of society is initially discussed. High-quality pre-school education for children gives them a strong start in their educational career and investment into effective education during the pre-school age provides a social and economic return to the whole of society. The following section defines the term quality and its interpretation in relation to education. Quality is interpreted through structure and process, the multi-dimensionality of quality and the objectiveness and subjectiveness of the interpretation of the quality of pre-school education are reflected. The interesting but undervalued position of parents, the perspectives of which are elaborated on in subsequent passages, appear in these concepts. This paper comes to two main conclusions. The first is that the quality of education is a multi-dimensional, variable and difficult to define concept. The second is that, although the status of parents in relation to pre-school education is strong, it is not adequately taken into consideration during definition of quality. When evaluating quality the perspective of the parents is only utilised to a limited degree, because it usually has different semantics to evaluation by experts.
\end{abstract}

Keywords: quality of education, perspective of parents, pre-school education, conceptualisation

\section{Introduction}

The basis of this paper is clarification and interpretation of relations originating at the intersection of three phenomena: quality in education, preschool education and parents of children as consumers of this education. We share opinions supporting the importance of pre-school education, which have resonated in pedagogic discourse during the last decades. The increasingly stronger voices of all those who are involved in education of children before they 
start primary school are based on a growing amount of empiric evidence that systematic institutional education of children of pre-school age is effective for both society in its more distant perspectives and also for the further development of each individual child. The parents of the children always appear in context concerning any analyses in relation to pre-school education, but they are only minimally considered important actors on a declarative level.

Oft-repeated statements of the high rate of return on pre-school education do not always contain the adjective "high-quality". We consider it important to mention that the benefits of pre-school education must be clearly linked to its quality, which means clarification of this concept and its overlap into practice. Regardless of whether we mean a high-quality educational system, quality in preschool education, high-quality pre-school education, a high-quality nursery school or other pre-school facility. The objective of this paper is to seek answers to the question of what status the perspectives of parents have in these concepts on the background of a discussion of the concepts of quality of pre-school education.

For this, we utilise the synergy originating from a combination of analysis of existing discourse about the quality of pre-school education and the parents' position in this and subsequent synthesis resulting in conclusions about how this parental voice can be defined. Within the terms of analysis, we therefore reveal the interpretation of quality in pre-school education, and we endeavour to reflect various properties of phenomena and elements, which represent it. This particularly includes parent culture (parent cultures are perceived here in the broader context as the life styles of parents with children of pre-school age, which includes their convictions, attitude, shared values, preferences and the nature of the family's social-cultural background, which they create. We also interpret it as a structure of values in which they move, which they utilise and mediate to their children). We do not consider synthesis here to be simple assembly of partial elements into a whole, this is an operation based on revealing new relations and rules in regard to the issue in question. Combination of the outputs of this analytical approach leads to the conclusion that the voice and status of parents is strong, but is only utilised to a limited degree in the reality of education when evaluating quality. The final synthesis should form a basis for correct decisions, of which one could also more or less purposefully focus on the perspectives of parents and their children in relation to the actual quality of education.

\section{The importance of pre-school education}

Pre-school education is the first experience many children have with other children of a similar age and adults who are not family members. There are not only numerous benefits to this social experience, but children can also play, learn new things, develop and acquire a number of skills and abilities (OECD, 2019) at 
nursery school at a time when brain development accelerates. The experience acquired during this period is beneficial in various areas of their further development (Herschkowitz et al., 2002). Attention devoted to pre-school education should also be based on the fact that, apart from experience that preschool education is the first important phase in the development of every child, it is also a very critical phase with regard to overall development and lifelong learning, which is also very closely linked to its quality (Ugaste et al., 2013). The reflected criticality of this child development phase is therefore interlinked with the child's opportunity to develop and potentialities with regard to requirements for the quality of the provided care and education.

High-quality pre-school education provides children with a strong start on the path leading to better results in learning and in their further educational career. This is the perspective of economists who were the first to process this scheme. It states that investment into early childhood education is a cohesive strategy for supporting economic growth, because the economic future depends on establishment of an educated and qualified workforce (Heckman, 2013). It even considers when it is necessary to begin this education so that this support is as effective as possible. According to economic analyses, the highest rate of return on early education is generated from investments that are made as soon as possible, ideally from birth to five years of age. To achieve the biggest possible effect, the start of early education at the age of three or four appears too late (Heckman, 2013).

These facts are also reflected by the EU or OECD. According to the European Union Commission (2006, p. 3) pre-school education "has the highest rate of return out of the entire continuum of lifelong education, particularly for children from disadvantaged environments, furthermore, the results of this investment increase over time." The effort to identify children who deviate from the mainstream is wholly evident, and crucial according to some authors, in discussions of the importance and quality of pre-school education. According to Ball (1994), good pre-school education leads to immediate and permanent social and educational advantages for all children, particularly those from disadvantaged environments. This is why investments into high-quality and effective education provide a useful social and economic return to individuals and all of society.

It would be naive to believe that pre-school education is an indisputable guarantee of the optimum development of every child. The educational reality of pre-school facilities does not always contain elements of a high-quality educational environment. In addition, the intention to individualise approaches to each child, depending on its dispositions, possibilities and the social-cultural conditions within the families from which the child come to pre-school education seems to be extremely demanding. Many variables enter here, such as the general 
context of the educational system and the specific conditions in which the preschool educational programme is to be realized (Pianta et al., 2009)

Even though economists repeatedly state that all the factors that contribute to a child's personal success cannot be balanced, it is possible to make smart investments into remedying the differences that cause major and persisting issues endangering the success of individuals (Heckman, 2011). Again, we work with a clear equation here - fixing problems is more expensive than preventing them. Gaps in skills that play an important role when achieving results in adult age, appear very soon across social-economic groups. It seems that these occur before the beginning of formal education and persist until adult age.

It is the interpreted quality of pre-school education, its programme or the school in which it is realised, which may qualify the discussed positive effects. For example, Danish children from disadvantaged environments later had better educational outcomes thanks to pre-school support programmes, in the USA ${ }^{1}$ these successes were not always registered (Epsing-Andersen et al., 2012). There are also arguments that effects of intensive support for the development of preschool children may soon disappear (Claessens, \& Garett, 2014).

The findings of many studies demonstrate the benefits of high-quality preschool education for the child's further education and learning. (Kaiser, \& Bauer, 2017; Gordon et al., 2015; Barnet et al., 2012). However, we repeat that the positive impact of pre-school education depends on its quality (Janta et al., 2016; Melhuish et al. 2015; Slot, 2017; Sylva et al., 2014). Although discussions consider

1 There is a great tradition of supporting education during pre-school age in the direction of children and families from disadvantaged environments in the USA. In addition to the well-known Head Start programmes, this also includes for example Abecederian Early Childhood Intervention (Masse et al., 2002). The High Scope Perry Preschool Program, which originated as a research study focusing on the issue of whether access to highquality education can have a positive impact on children of pre-school age and which reflects the issues of the quality of education, is worth a special mention. It is also useful that the programme has its own quality indicators (https://highscope.org/ourpractice/child-assessment/pqa/) and currently contributes to establishment of capacity for permanently positive results and assurance of support for each teacher and the results each child. The programme supports local, state and national policies in the field of preschool education. According to this programme children to whom high-quality pre-school education was provided are better prepared for primary school, will be more emotionally mature and more independent, they have a higher study success rate, more stable employment and higher wages, create a more stable home environment for their children and are more involved civically (High Scope, 2020). The project also documents a high rate of return on investment into pre-school education. 
pre-school education for the child's development to be the most important, (Heckman, 2011; Litjens, \& Taguma, 2010; Knudsen et al., 2006), it is the "preschool education sector, which we know least about", and what probably disrupts this harmony most is that the provision of pre-school education is often fragmented, poorly regulated and non-unified (OECD, 2019, s. 3), therefore lower quality.

\section{Quality in education - definition of the issue}

In general, quality concerning education can be viewed as "the level of production created by an individual school, set of schools of a specific level, or type or the entire educational system of a country“ (Průcha, Walterová, \& Mareš, 2009, p. 111).

Discussions concerning the quality of education are often confusing, due to a lack of comprehensibility or common understanding of what the term quality actually means (Tawil et al., 2014). The term quality evokes a seemingly intuitive understanding. However, there is no single definition or approach, but rather a diverse conceptualisation and substantially varied approaches, of which each is based on different assumptions. Various evaluators (students, parents, teacher, employers, auditors) perceive quality from different perspectives, but uniformly anchored on the platform that "high-quality is positive". This is understandable if we base our knowledge on the meaning of the Latin qualitas, which identifies a property or quality. The concept of quality is framed in ordinary communication using adjectives, or more precisely identification of something as high-quality, or good, optimal, suitable, fulfilling several requirements. ${ }^{2}$

On one hand, quality in education is essential (Jirečková, 2011), on the other hand, it requires courage to open this topic (Janík, 2010). It is in the interests of the whole of society, not only the providers or consumers of education. It also concerns a relative concept in relation to services provided by schools. In general, high-quality educational programmes are based on standards in several areas academic, social-emotional and physical. Quality in education is subsequently diversified into interpretations anchored in relative concepts - quality of education or quality of (nursery) schools, subsequent quality of education, quality of teachers, etc. Quality (of educational processes, educational institutions, educational systems), or quality in education "is considered the desirable (optimum) level of functioning or production of these processes or institutions, which may be prescribed by specific requirements (e.g. educational standards) and may therefore be objectively measured and evaluated" (Průcha, 1996, p. 27).

${ }^{2}$ A very good analysis of the meanings and methods of using the concept of quality in education in the Czech interpretation, is available from Janíka et al. (2013). 
Quality in education leads into the quality of schools. Some authors perceive the quality of a school more from a managerial perspective, when the quality of operation of the organisation, which is assured especially by effective management within the meaning of the school's philosophy, is pursued. For instance, Spílková (2005) includes a high-quality system of school management, a high-quality teaching staff, a predominating progressive didactic concept and the school's authenticity, among the criteria for the quality of a school. Other definitions emphasise consideration of the individual needs of children and inspection and assessment of the school's steps to fulfil its vision. The aforementioned authenticity of the school resonates more in the next interpretation, according to which a high-quality school "regularly establishes, takes into consideration and endeavours to fulfil various expectations (and to a specific degree also the wishes and needs) of its customers and endeavours, within the terms of its potential, to keep the matter in a good state and make overall improvements by regularly fulfilling the goals it has set, however, everything is managed using common sense: a high-quality school therefore meaningfully realises auto-evaluation processes, it is a learning school" (Vašt’atková, 2006, p. 25).

Just as parents interpret the quality of a school and education differently, the teachers and the heads of schools are also not unified in their opinions. The heads themselves state that quality is a fairly broad term and on what level of the school's quality its definition and evaluation ranges on must be minimally qualified. Some heads consider this to be the children's and pupils' outputs, level of mediated motivation for performance by children, others how current the educational content is in regard to the needs of society, the ability to arrange equal opportunities etc. (Štefflová, 2011). The term quality is difficult to uniformly grasp from both the aspect of practice and theory, however this is helped by definition of the areas in which quality is to be evaluated. Quality is often defined through the perspective of standards, which are determined by experts, potentially other involved parties. Experts endeavour to interpret the criteria for the quality of education and educational institutions consistently, problems appear in the case of others who are involved in the education process.

Research by Dahlberg, \& Moss (2007) resulted in the following important findings in regard to the aspects from which quality is viewed:

a) the process of definition of quality eliminated a wide range of involved parties and is based mainly on a small group of experts,

b) quality is a subjective, value-orientated, relative and dynamic concept, which is why various perspectives must be taken into consideration during its definition. 


\section{Interpretation of the quality of pre-school education}

On the basis of arguments, according to which interpretation of quality is polymorphous, difficult to define and interpret by various involved parties, it was proposed that the quality of education should be evaluated from various perspectives, particularly with regard to the goal of creating a global picture about pre-school education programmes (Rentzou, \& Sakellariou, 2013).

\section{Interpretation of quality through structure and process}

The question of what is measured and reported as quality in education is asked by many experts. For instance Slot et al (Slot et al., 2015) refers to popular classification based on a concept through structure and process. Diagram 1 shows the relationship between structural quality, process quality and the child's development and learning in pre-school education, (Slot, 2017). Both layers of quality overlap, conditioning the child's development and learning.

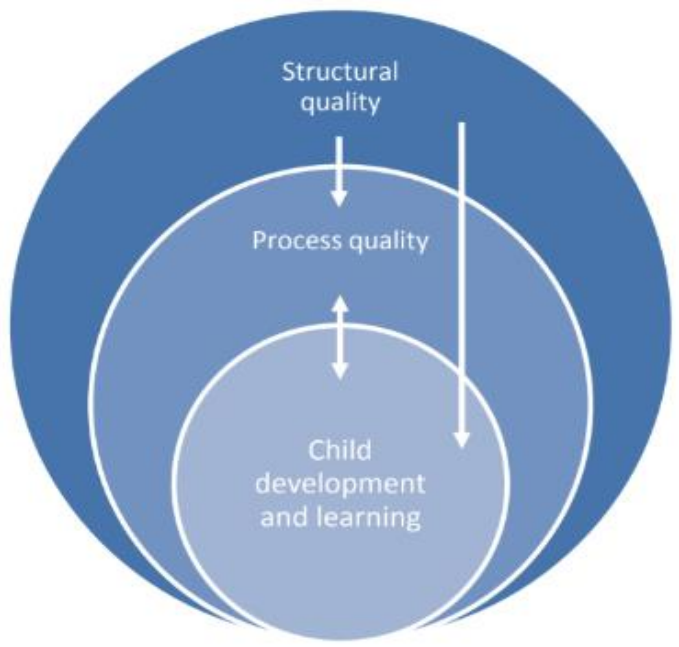

Fig. 1: Relationship between structural quality, process quality and child learning and development in preschool education (Slot, 2017, in OECD, 2018, p. 26).

Structural elements independently integrate variables, which indirectly influence child experience during pre-school age, for instance the number of children in a class, the ratio of teachers to children and the education of the teachers. The structural standards based on these are fairly easy to configure and observe by both inspections and parents (for instance sufficient space for children, the quantity and nature of didactic equipment, etc.). Authors Litjens and Taguma (2010) describe structural quality as inputs into process characteristics, which create a framework for the processes that children experience. An environment 
considered structurally high-quality has a small group, a teacher with high qualifications, meets hygienic standards and adheres to the curriculum. This quality is usually measured by human, financial and time resources (Janta et al., 2016).

The quality of the process concerns dependent variables related to child experience within the terms of education. It refers to aspects of the environment in the class, which the children experience - their interactions with teachers and peers, the materials and activities they have available (Harrist et al., 2007). These aspects affect child experience, comfort and development (Litjens \& Taguma, 2010). This type of quality is therefore measured by processes, which focus on relations between employees and children, communication with families and broader community support services. An environment considered high-quality in the field of the process is distinguished by frequent interactions between the child and employees, a stimulating curriculum and effective pedagogic procedures (Janta et al., 2016). The relationship between structural quality indicators, process quality indicators and the results of pre-school education is shown in Figure 2.

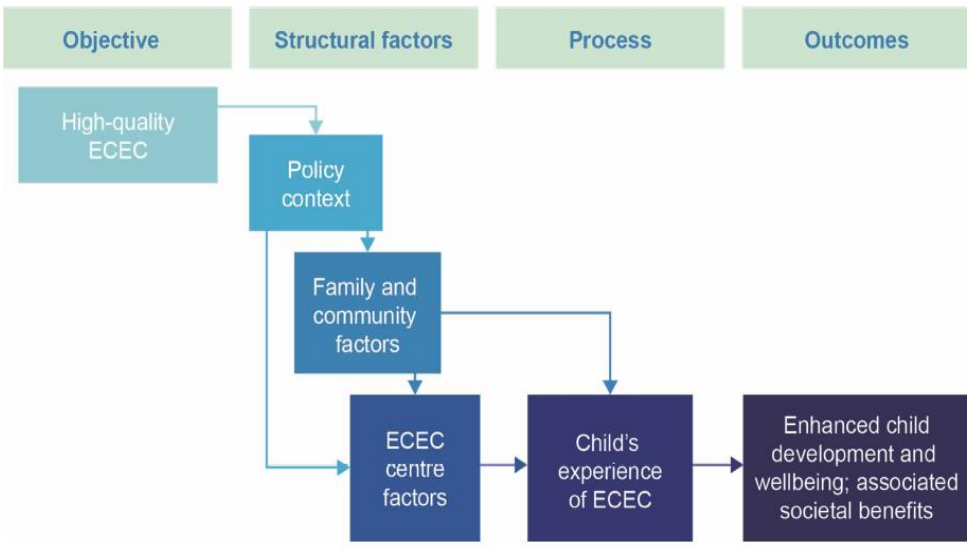

Fig. 2: Quality in relation to structural indicators - process indicators - results of education (Janta, 2016)

Basically, the structure and the process are important in relation to quality. They are mutually interconnected, which is why seeking ways to make the ideal high-quality preschool education into reality emphasises the importance of both. According to research, the process aspects, or the quality of interactions into which they enter with employees and other children in pre-schools on a daily basis (OECD, 2019), are the main contributors to the learning, development and good 
life perspectives of children. On the other hand, several factors are identified in the results that may affect the quality of these interactions, from preschool employees and the extent to which they are educated, trained and motivated to work with children, through elements of the class, playrooms environment, such as the number of children and staff, to mechanisms for monitoring configuration of preschool education (OECD, 2019). However, the results are not completely consistent with regard to which structure and process properties are determinative or crucial for quality.

Relations between structure and process quality in pre-school education have been examined, but with fairly inconsistent findings (Pianta et al, 2005). One potential explanation is that structural characteristics may be more indirectly linked to children's results because they provide a basis for the quality of the process as a primary mechanism for child learning and development. However, studies directly focusing on the indirect impact of structural quality on child learning and development are limiting and demonstrate a mixed formula of associations (Anders, 2015).

This phenomenon is also demonstrated by research carried out in Sweden, Austria and Bulgaria, where preschool teachers were asked about their viewpoint of quality. Researchers Brodin et al. (2015) emphasise interesting findings with regard to the varying concept of quality, despite the limited research sample (3 countries). They state the teacher's approach and pedagogic planning, which depend significantly on the teacher, while class size or the number of teachers, is outside their competence. In general, this study indicates that the teachers consider both structural and process elements to be important for high-quality pre-school education, but to different levels.

Despite these findings, structural factors were preferred as a crucial strategy for improving the quality of early education programmes and, ultimately, for child learning and development. For instance, in many countries increasing the qualification requirements placed on employees is a chosen quality strategy (Early et al., 2007). ${ }^{3}$ Another example is the situation in the USA, where quality criteria, which also fulfil the character of the aforementioned structural elements, are generated. The authors (Lewis, \& Burd-Sharps, 2011) give unified standards for education, bachelor's education for teachers, a maximum number of children in a class - 20 (ratio between staff and children 1:10), one nutritional meal a day,

${ }^{3}$ In the Czech Republic for instance, there is emphasis on increasing the qualification of teachers to a university level, on the level of a declaration in strategic documents, specifically in the Strategy of the educational policy of the Czech Republic until 2020 and its implementary document Long-term plan for education and development of the educational system in the Czech Republic for the 2015-2020 period. 
guaranteed healthcare, teacher's visits to the child's family, further education of teachers in the scope of at least 15 hours a year, etc. as criteria.

\section{Quality as a multi-dimensional construct}

Research of the quality of education is not a new topic; on the contrary, since the 1960s, this topic of research has drawn the attention of many scientists and has undergone various phases (Ceglowski, 2004; Melhuish, 2001). However, its concept differs. In this early research quality was perceived more as a luxury than a necessity according to Kagana et al. (1996). Today quality is much more important. In addition, athough research of issues concerning the quality of care and education of children of pre-school age quickly spread, it also developed in many other aspects. Awareness of its context, measurement, complexity, plurality and subjectivity has increased (Dahlberg et al., 2007).

It is evident from just a few of the already discussed definitions that authors differ in the depth and also in the breadth of their view of quality. Some of them (Iruka, \& Forry, 2018; Pianta et al., 2002, tc.) therefore call quality as a multidimensional construct.

Description of quality, as a multi-dimensional complex construct, which includes the structure of pre-school education, processes and practice in setting of pre-school education and its results, can be found in the approaches of the European Commission (2014). This conceptualisation covers global aspects (such as a pleasant climate or the appropriate approach to children) and specific stimulation from the domain aspect in areas such as literary, mathematical and natural science pre-literacy (Anders, 2015).

Definition of the dimensions of quality (as a multi-dimensional construct) is therefore considered crucial for revealing the basis of quality. These dimensions can be specific for each kindergarten and usually also exceed the framework of the determined quality criteria, particularly when here, in the Czech Republic, nursery schools participate in determining the content of education when creating school educational programmes for example.

The dimension of quality includes the relationship between the teacher and the child, the activities and materials related to educational activities, organisation and management of childcare and the relationship between the family and teacher. Evaluation of the dimensions of quality can differ depending on the type of programme or the characteristics of the providers (Iruka, \& Forry, 2018). Several studies investigated relations between the dimensions of quality and the children's results (Burchinal, 2018; Early et al. 2007; Pianta et al., 2002). However, studies focusing on the investigation of the multi-dimensionality of quality pattern are however unique. Understanding qualitative patterns across various dimensions 
helps during professional development of teachers and during initiatives focusing on increasing quality.

The basis for a multi-dimensional understanding of quality is the educational environment, in which children are involved in developmentally suitable, stimulating and language-enriching activities, which offer opportunity for play and discovery, use of language, problem-solving and social interaction (European Commission, 2014; OECD, 2018). Definition of the dimensions of quality and its key indicators, which exceed those that are usually regulated, seems to be unavoidable for improvement of quality.

\section{Objectivity and subjectivity in the interpretation of quality}

As already mentioned, quality in education is a very complicated construct, the concepts of which are very diverse and in relation to which development can also be recognised. Alasuutari (2014) states that re-conceptualisation of the term quality must be considered, because, according to him, quality is a constantly changing process leading to a specific state. Moss (2016) considers whether quality is essential or an option. Various studies conceive quality in different ways. Even the word quality is highly disputable, it can be said that it is a subjective concept, which depends on context and enables various perspectives and modifications over time.

Definition of quality depends on the philosophy and strategy of the national curriculum, social-political priorities, cultural aspects and qualitative elements, such as pedagogic, financial or physical decisions. There is therefore no single concept or method for determining quality. Quality as a concept is not defined in the field of education and is problematic. In education, quality is linked to subjective evaluation, the individual concepts of quality by its participants are expressed in it. This interpretation of quality is understood to mean the participants' achieved degree of satisfaction with the school's activity. Quality can also be evaluated from the objective aspect. According to this aspect, quality is determined without the context of variables. An objective perspective of quality is constructed through experts and their objectivity (Parrila, 2002). In the case of pre-school education, the subjective evaluation model takes into consideration the experience of teachers, parents and children and their satisfaction with pre-school education. The objective model does not take into consideration the opinions of participants of pre-school education, but rather verifies, uses indicators to measure, quality from the viewpoint of experts.

Quality is also assessed from the inter-subjective aspect, which means that quality is normally focused on all participants and is also part of the character of mutual relations between individuals. The inter-subjective viewpoint of quality is 
described by teachers', parents' and children's subjective concepts of pre-school education.

Both the objective and subjective approach is emphasised for complex interpretation of quality. Quality of education is an important factor for improving child learning, particularly in the field of literacy, mathematics, scientific thinking and social development (Sylva et al., 2006).

Katz (1999), who acknowledges that various people can define quality variously, proposed five perspectives for evaluating quality, which reflect this. This concerns:

1. "top-down perspective", which is also called the perspective of research workers - professionals, and which evaluates the characteristics of the programme, how it is viewed "from above" by persons responsible for the programme;

2. "bottom-up perspective", which endeavours to determine how the programme is actually experienced by the involved children;

3. "outside-inside perspective", which assesses how the programme is experienced by families;

4. "inside perspective", which considers how the programme is experienced by its employees;

5. "outside perspective", which takes into consideration how the programme serves the community and broader society.

Although Katz (1999) proposed this concept for evaluating quality 20 years ago, it remains inspirational. New information sources show that research focuses on the "perspective from above" in most cases, the remaining four perspectives are studied quite rarely and the child perspective absolutely minimally (Rentzou, 2011). Katz's third perspective, which takes into consideration how parents perceive the quality of education, is also neglected. We will focus on this below.

\section{Parents in relation to definition of the quality of pre-school education}

Quality in pre-school education is indisputably interlinked with parent culture. The status of parents appears in every approach or concept of quality. We perceive parents in the process aspect of quality, they provide a subjective viewpoint during assessment and therefore also during definition of quality, they are indisputably protagonists of some dimensions of quality as a multi-dimensional construct, the parental perspective ("outside-inside" according to Katz, 1999) also helps significantly during efforts to clarify it more complexly. Whatever the diversity in interpreting the concept of quality in pre-school education, parents of children always appear in it in some context. Findings from investigation of quality from a perspective other than from the viewpoint of experts contribute to establishment 
of the meanings that are related to important and complex interpretation of quality in education.

Definition of the interpretation of quality depends on the expectations of the members of the social group (parents, children/pupils and teachers) who are involved in education. Various groups of respondents often present factors that determine quality ambivalently, because these respondents usually link them to various, often subjectively oriented needs and expectations.

Parents also have various expectations of pre-school facilities, which include provision of a high-quality education (Sevinc, 2006). One definition of a highquality school is understood through establishment, consideration and fulfilment of the various expectations and needs of children and parents (e.g. Vašt'atková, 2006; Krnjaja, \& Pavlović-Breneselović, 2013).

Parents who expect the highest-quality education provided by qualified pedagogues are identified as "client parents" (Rabušicová, et al., 2004). However, these expectations are not always unified (Barkauskaitè et al., 2013) and often differ depending on the level of achieved education, social-economic status and different demographic data concerning the parents (Bayrak, \& Koksal, 2017; Jacobson, \& Engelbrecht, 2000). These are different cultures, which parents create and endeavour to transfer to the kindergarten through their requirements. ${ }^{4}$ Although these expectations or requirements may differ from the school itself, they are connected by a single vision, this being to ensure optimum development of the children (Rabušicová et al., 2004). If the parents do not find the relevant response to their visions, requirements or expectations in the school, they seek other suitable schools or "abandon the system" and establish their own parental schools, or choose to educate their children at home.

Parents are key factors during selection of schools, including kindergartens. Their subjective viewpoint of the quality of a school is crucial during selection of the school, across all levels of education. The subjective criteria of the quality of schools also depends on the types of schools that the children attend or will attend. For parents, the quality of a school is usually reflected during its selection in their expectations, which reflect their varied perspectives and personal preferences,

\footnotetext{
${ }^{4}$ We have experience with the academic parent culture, parents whose children attend the University kindergarten. The kindergarten is established by a public university and operates as a corporate private school. One of the authors is in the School Board and has also executed research in it. According to the results of this research the parents mirror not only their social-economic status, but also the environment in which they are professionally active, in their expectations to a specific degree. They are capable of very clearly declaring their requirements for the professionalism of its teachers, the offer of above-standard school activities, the stimulation and diversity of educational activities, etc. (Majerčíková, 2019).
} 
closely linked to the prosperity of their child, support of its potential, maximization of its development, registration of potential problems concerning the child, etc. ${ }^{5}$ The group of researchers around Glenn-Applegate (et al., 2016) examined the factors that play a role when parents select a nursery school. These factors were also compared to the quality of education in individual classes. Findings showed that when selecting a kindergarten, parents preferred the interpersonal characteristics of the teacher and the safety of the kindergarten. Parents also preferred process elements of quality over structural elements. No link was found between the factors for selection of kindergartens and the quality of the classes in which the children were enrolled.

This means that, for parents, quality is more personality orientated - linked to the teaching staff, their education, their positive relationship with the children and their experience with them. In relation to the school, quality is interpreted in relation to an age-appropriate programme, the quality of the physical and social environment or the overall cleanliness of the environment.

As interpreted by the parents, quality is formed on the basis of their expectations (Krnjaja, \& Pavlović-Breneselović, 2013). Various social values are reflected during contextualisation of quality in education. This is why it is initially important to ask questions about how we understand the nature of childhood, what attitudes and skills we want to promote in the children or who is actually responsible for the upbringing of children, etc. The answers to these questions may be culturally or politically qualified (Malovic et al., 2017). Research by authors around Brodin et al. (2015) found a difference in the understanding of quality of kindergartens by parents, in relation to social, cultural and financial questions, depending on the social situation in individual countries. Quality is therefore determined by the society in which the parents live and their personal experience and concepts of education and can be differentiated from the perspectives of experts in the field of education (Malovic et al., 2017).

A comparison of these perspectives is suggested. Interesting research executed by Rentzou, \& Sakellariou (2013), when evaluation of the quality of pre-school education from the perspective of parents and researchers is compared, provides a specific depiction of this issue. A correlation analysis showed that parents assessed the quality of care and education as higher-quality compared to researchers. It was also found that the age and level of education of the parents correlates with their assessment. In this case the results of research again confirm that the quality of pre-school education is a relative concept. They also emphasise

${ }^{5}$ We consider the testimonies of parents, available at https://www.parenthub.co.uk/whatdo-parents-expect-from-schools/, inspirational. 
the need to take into consideration the perspectives of all the involved parties (parents, children and teachers) during attempts to define and evaluate quality.

Parrila (2002) presents a finding regarding the different perspectives of parents and staff of kindergartens in fields such as the personality and professionalism of employees, the function and functionality, the goals of the kindergartens and the impact of pre-school education.

Tauriainen (2000) analysed the concept of the quality of kindergartens of employees, parents and even the children. The results showed that the common principal of good quality is a small group of children and employees, an emotionally pleasant environment and improvement of self-motivating behaviour in children. The results also confirmed that employees, parents and children perceive quality in their own ways. Employees had a very general concept of quality, which concentrated on managing activities and the smooth progress of the daily routine, for parents the individual needs of their children and social interaction within the group played a role and for the children themselves the aspects of cooperation with adults and freedom in planning their activities were important aspects (Tauriainen, 2000).

The ambitious plan to take into consideration various perspectives of the quality of pre-school education should be preceded by clarification of what its actors derive the quality of education from. A study by researchers Navarro-Cruz, \& Luschei (2020) examined the factors that mothers of children found represented the quality of kindergartens. Mothers most often chose pre-school facilities on the basis of recommendations on social networks, access to the school and financial accessibility. They then concentrated on facilities that were safe, have trustworthy staff with a loving attitude to the children, cooperated with parents, whose educational programme suited the needs of the family and finally had a low teacher to child ratio. The analysis also demonstrated, or more precisely confirmed, that the preferences of mothers are based on their past and current experience.

Studies usually encourage a new definition of quality, which emphasises the importance of appreciation of the parent culture and the context and uniqueness of the parents' wishes for their children. When understanding the conditions that families seek for their children in pre-school facilities, teachers are able to better integrate these preferences and thereby appreciate the benefit of family.

\section{Summary and discussion}

Quality is generally interpreted as a relative but not random concept (Woodhead, 1998) and also as multi-faceted and problematic (Giota, 1995). Quality can be constantly redefined depending on how its individual components are operationalized (Fontaine et al., 2006). This is not objective reality, but a relative value depending on the person who provides the information about 
quality and which can be variously perceived by the parent, the teacher or even the child itself (Barnes, 2001).

Involvement of parents in pre-school education allows them to actively participate in the school and out-of-school life of the school, and also contributes to the successes of the pre-school educational programme (Dogrul, \& Akay, 2019). This is naturally to the benefit of the child of each parent. Their participation in the processes of conceptualisation of quality seems justified.

When defining quality, this does not have to be a "gold standard", which applies to all situations and contexts (Dahlberg et al., 2013). We believe that we must accept the conclusion that quality depends on a number of functions of pre-school education, which may differ in various settings. These traits may combine various levels, for instance interaction between the child and the teacher, the class, the school climate, policy or view of pre-school education in various countries or even districts (Hujala et al., 2012).

Children who acquire solid foundations for learning in pre-school age, also thanks to a high-quality and systematic institutional education, should have better educational and life perspectives in the future (Melhuish et al., 2015). This vision should be fulfilled with the significant involvement, support and participation of the parents of children, potentially by compensation when parents fail. According to Bayrak and Koksal (2017) parents are important actors in pre-school education and also valuable sources during research in this field of education.

Involvement of parents in pre-school education is most intensive when compared to other levels of education. Pre-school facilities often declare that cooperation with parents is problematic, teachers complain about the difficulty of meeting their requirements and expectations. During pre-school education parents must cooperate more with regard to the age of the children, they must clearly declare their specific expectations related to fulfilment of their requirements. Despite a common vision of close cooperation between the school and the family, parents do not have an easy position in the field of education. The reason for this may be that they act individually and not as an organisation, as a group with unified attitudes and intentions, when dealing with specific situations. However, this method of participation is not supported in the educational process (Kalous, \& Veselý, 2006). Even though it must be mentioned that pre-school education provides the best conditions and psycho-social conditions for this, an individual approach to the child is most often utilised in nursery school. Furthermore, parents are also neglected creators of educational policies (Bell, \& Stevenson, 2006; Dahlberg, \& Moss, 2007), which indicates their problematic position when determining what we can consider high-quality in pre-school education. 
Even though the voice of parents is examined, identified and appreciated in pre-school education, according to our analysis the concept of quality does not take parents into consideration. Many proposals are directed towards reconceptualization of quality in education. However, we have not yet discovered an explicitly formulated conclusion that parents should be heard more in these new concepts. It seems that parents are considered amateurs, pedagogic laymen, who over-rate the situation and have no awareness of what is actually happening at the kindergarten, and are therefore unable to assess what quality means (Cost, Quality and Outcomes Study Team, 1995). Furthermore, according to experts, parents do not even have the tools to evaluate quality (Malik et at., 2016), they are incapable of assessing which are the relevant indicators of quality. Their evaluation is based on feedback from their children (of pre-school age), who are not yet able to provide a real description of what is happening at pre-school and how education is taking place.

To reflect this situation, there are also interesting suggestions from Rosenthal and Vandell (2013), who claim that parents evaluate the quality of primary school better, because they have more experience with these educational institutions, compared to kindergarten, which is at the beginning of the child's education journey. They also dispute the actual expectations of parents, which have a different content and a more or less real basis and the actual lack of real experience is considered a disqualification point for "pre-school" parents. The crucial result that they are nearly always satisfied, that education is nearly always high-quality in their opinion and better, compared to assessments by experts, is probably the weakest point of these parents (Rentzou \& Sakellariou, 2013).

Our analyses lead us to the conclusion that despite the fact that the importance of the role of parents is utilised intensively in pre-school education and in many aspects, their voice is not adequately listened to when defining its qualities. We endeavoured to reflect the place of parents in how quality itself can be defined, specified and conceptualised, and what we should consider high-quality in education. For the time being, experts have the mandate to clarify the issue. But we can also find ourselves in a situation where what seems to be high-quality in pre-school education for parents, may not necessarily correspond to expert opinion and vice versa. If parents did not declare their interests and opinions, or took their children to kindergartens without complaints, the continuity of the influence of both environments, school and family, could be preserved. However, imbalances can be expected in situations when a parent does not agree or has other visions and declares these. The child itself gets the worst of this situation, discord or unresolved animosity between both parties can be an obstacle to its expected development and prosperity. 
Different perspectives and attitudes in evaluation of quality are not a problem. But what is a real problem according to Dahlberg, \& Moss (2007), is when others assume the attitude that there are no other involved parties and their viewpoint is the only viewpoint. Although the right to accept various perspectives is defended, this is only with the major reservation that "everyone involved in the institution of pre-school education understands the existence of various perspectives and that the work that the parents, the creators of policies or research workers carry out, always provides a specific viewpoint, on which decisions or appreciation of values are based, from which consequences are derived in theory and practice" (Dahlberg et al., 2007, p. 119). However, mutual respect and reflection of each other's opinions and needs can be discussed further.

\section{Conclusion}

Parents therefore have much to say when defining quality in education, even though the plan to conceptualize quality in pre-school education is especially complicated. Determination of specific quality criteria is usually the work of experts, ideally the result of social accord. The question is whether this should take place only on the level of professionals, as it has to date.

Quality is neither natural nor neutral and it can therefore not be considered a matter of course. How can quality take into consideration context and values, subjectivity and plurality? How can it satisfy various perspectives, when various groups in various places have different viewpoint of what quality should be or interpret its criteria differently? This problem became more urgent when the importance of the process of determination of quality and also how it should be accepted by all involved parties, not just academic experts, but also children, parents and teachers, began to be discussed (Dahlberg \& Moss, 2007). Although converting the viewpoint of parents into indicators of quality is a difficult task, it can certainly be reflected. Whether these can be interconnected with the perspectives and survival of the children themselves, who are not only omitted from this topic and who, as we stated previously, also have a contribution to make in relation to definition of quality, could also be considered. Especially when children today are considered actors in their own education and in their own lives and create a social group, which has its own place in the social structure and in inter-generational relations. Childhood is a distinctive, socially constructed phase of life. From this aspect, children, as actors in education, are entitled to enter processes related to assessment of its quality. This could be another challenge in relation to the topic of quality in pre-school education. 


\section{References}

Alasuutari, M. (2014). Assessment and Documentation in Early Childhood Education. UK: Routledge.

Anders, Y. (2015). Literature review on pedagogy in OECD countries. Paris: OECD. http://www.oecd.org/officialdocuments/publicdisplaydocumentpdf/?cote=E DU/EDPC/ECEC\%282015\%297\&docLanguage=En

Ball, Ch. (1994). The importance of early learning. London: Royal Society for the Encouragement of Arts. https://files.eric.ed.gov/fulltext/ED372833.pdf

Barnes, J. (2001). Using observations to evaluate paid child care settings. In K. Petrogiannis \& E.C. Melhuish, Early childhood: Care - education - development: Findings from international research (pp. 395-446). Athens: Kastaniotis. In Rentzou, K., \& Sakellariou, M. (2013). Research's and parents' perspectives on quality of care and education. Early Child Development And Care, 183(2). https://www.researchgate.net/publication/254228414_Researcher's_and_pa rents'_perspectives_on_quality_of_care_and_education

Barnett, W.S., Carolan, M.E., Fitzgerald, J., \& Squires, J. H. (2012). The state of preschool 2012: State preschool yearbook. New Brunswick, NJ: National Institute for Early Education Research.

Barkauskaitė, M., Žygaitienè, B., \& Miškinienè, M. (2013). The Conception and Factors of Education Quality at Lithuanian Schools of General Education. Procedia - Social And Behavioral Sciences, 83(4), 170-174. https://www.sciencedirect.com/science/article/pii/S187704281301063X

Bayrak, S. \& Koksal, O. (2017). Examining the expectations of parents from preschool education (Sample of Elazığ province). The Journal of Academic Social Science, 5(45), 547-557. http://dx.doi.org/10.16992/asos.12395.

Bell, L., \& Stevenson H. (2006). Education policy: process, themes and impact. New York: Routledge, Leadership for learning.

Brodin, J., Hollerer, L., Renblad, K. \& Stancheva-Popkostadinova, V. (2015). Preschool teachers' understanding of quality in preschool: A comparative study in three European countries. Early Child Development and Care, 185(6), 968981

Burchinal, M. (2018). Measuring early care and education quality. Child Development Perspectives, 12(1), 3-9. doi:10.1111/cdep.12260

Ceglowski, D. (2004). How stake holder groups define quality in child care. Early Childhood Education Journal, 32(2), 101-111.

Commission of the European Communities (2006). Communication from the commission to the council and to the european parliament. Efficiency and equity in european education and training systems. Retrieved from: https://eurlex.europa.eu/legalcontent/EN/TXT/PDF/?uri=CELEX:52006DC0481\&from=CS 
Claessens, A., \& Garrett, R. (2014). The role of early childhood settings for 4-5 year old chil- dren in early academic skills and later achievement in Australia. Early Childhood Research Quarterly, 29(4), 550-561. Available on: http://doi.org/10.1016/j.ecresq.2014.06.006

Commission of the European Communities (2006). Communication from the commission to the council and to the european parliament. Efficiency and equity in european education and training systems. Retrieved from: https://eurlex.europa.eu/legalcontent/EN/TXT/PDF/?uri=CELEX:52006DC0481\&from=CS

Dahlberg, M., \& Moss, P. (2007). Beyond Quality in Early Childhood Education and Care - Languages of Evaluation. Cesifo Dice Report, 6(2), 21-26. https://www.researchgate.net/publication/227383645_Beyond_Quality_in_E arly_Childhood_Education_and_Care_-_Languages_of_Evaluation

Dahlberg, G., Moss, P. \& Pence, A. (2013). Beyond quality in early childhood education and care: Languages of evaluation (3rd edn). London: Routledge.

Dogrul, H. \& Akay, C. (2019). Comparision between Syrian and Turkish Parents Opinions and Expectations about Pre-School Education. Journal of Social Sciences 6(36), 119-139. https://files.eric.ed.gov/fulltext/ED603178.pdf

Dlouhodobý záměr vzdělávání a rozvoje vzdělávací soustavy České republiky na období 2015-2020. (2015). Praha: MŠMT. Retrieved from: http://www.vzdelavani2020.cz/images_obsah/dokumenty/strategie/dz-rgs2015-2020.pdf

Early, D. M., Maxwell, K. L., Burchinal, M., Alva, S., Bender, R. H., Bryant, D., \& Zill, N. (2007). Teachers' education, clasroom quality, and young children's academic skills: Results from seven studies of preschool programs. Child Development, 78(2), 558 - 580. 10.1111/j.1467-8624.2007.01014.x

Esping-Andersen, G., Garfinkel, I., Han, W. J., Magnuson, K., Wagner, S., \& Waldfogel, J._(2012). Child care and school performance in Denmark and the United States. Children and_Youth Services Review, 34(3), 576-589. Dostupné z http://doi.org/10.1016/j.childyouth.2011.10.010

European Commission (2014). Key principles of a quality framework: Proposal for key principles of a quality framework on early childhood education and care. Report of the working group on early childhood education and care under the auspieces of the European Commission. http://ec.europa.eu/assetes/eac/education/policy/strategicframework/archieve/documents/ecec-quality-framework_en.pdf

Fontaine, N.S., Dee Torre, L., Grafwallner, R., \& Underhill, B. (2006). Increasing quality in early care and learning environments. Early Child Development and Care, 176(2), 157-169. In Admas, F. (2017). Early Childhood Education in Ethiopia: Present Practices and Future Directions. The Ethiopian Journal of 


\section{Education 36(2), 41-72. Retrieved from:} https://www.researchgate.net/publication/338478340_Early_Childhood_Edu cation_in_Ethiopia_Present_Practices_and_Future_Directions

Giota, J. (1995). ECERS as research instrument: Statistical analyses. Paper presented in the 5th European Conference of the European Early Childhood Research Association on the Quality of Early Childhood Education, Sorbonne, Paris. In Rentzou, K., \& Sakellariou, M. (2013). Research's and parents' perspectives on quality of care and education. Early Child Development And Care, 183(2).

https://www.researchgate.net/publication/254228414_Researcher's_and_pa rents'_perspectives_on_quality_of_care_and_education

Gordon, R. A., Hofer, K. G., Fujimoto, K. A., Risk, N., Kaestner, R., \& Korenman, S. (2015). Identifying high-quality preschool programs: New evidence on the validity of the Early Childhood Environment Rating Scale-Revised (ECERS-R) in relation to school readiness goals. Early Education and Development, 26(8), 1086-1110.

Glenn-Applegate, K., Justice, L., \& Kaderavek, J. (2016). How Do Caregivers Select Preschools? A Study of Children with and without Disabilities. Child \& Youth Care Forum, 45(1), 123-153. https://eric.ed.gov/?q=preschool+quality\&id=EJ1087189

Harrist, A., Thompson, S., \& Norris, D. (2007). Defining Quality Child Care: Multiple Stakeholder Perspectives. Early Education \& Development, 18(1), 1-32.

Heckman, J. J. (2011). The Economics of Inequality: The Value of Early Childhood Education. American Educator (35)1, 31-35.

Heckman, J. J. (2013). Invest in early childhood development: Reduce deficits, strengthen the economy. Heckman The economics of human potential. Retrieved from: https://heckmanequation.org/www/assets/2013/07/F_HeckmanDeficitPiec eCUSTOM-Generic_052714-3-1.pdf

High scope (2020). Who we are. Available from: https://highscope.org/who-weare/

Herschkowitz, N., \& Herschkowitz, E. (2002). A Good Start in Life: Understanding Your Child's Brain and Behavior. National Academies Press: New York.

Hujala, E., Fonsén, E., \& Elo, J. (2012). Evaluating the quality of the child care in Finland. Early Child Development and Care, 182(3-4), 299-314. doi: 10.1080/03004430.2011.646721

Iruka, I., \& Forry, N. (2018). Links Between Patterns of Quality in Diverse Settings and Children's Early Outcomes. Journal Of Education,198(1), 95 - 112. https://journals.sagepub.com/doi/full/10.1177/0022057418800941 
Jacobson, A. L., \& Engelbrecht, J. (2000). Parenting education needs and preferences of parents of young children. Early Childhood Education Journal, 28(2), 104-116.

Janík, T. (2010). Integrace idejí zaměřených k profesionalizaci učitelství. Pedagogika, 60(3-4), 329-341.

Janík, T., Slavík, J., Mužík, V., et al. (2013). Kvalita (ve) vzdělávání: obsahově zaměřený př́stup ke zkoumání a zlepšování výuky. Brno: Masarykova univerzita. Janta, B., Janna van, B., \& Stewart, K. (2016). Quality and impact of Centr-based Early Childhood Education and Care (1st ed.). RAND Corporation. https://www.rand.org/pubs/research_reports/RR1670.html

Jirečková, I. (2011). Kritéria kvality školy z pohledu České školní inspekce a systému řízení kvality ISO a CAF. Pedagogická Orientace, 21(1), 70 - 84.

Kagan, S., Cohen, N., \& Neuman, M. (1996). Introduction: The changing context of American early care and education. In S. Kagan \& N. Cohen (Eds.), Reinventing early care and education: A vision for a quality system (pp. 1-17). San Francisco: Jossey-Bass.

Katz, L. G. (1999). Multiple perspectives on the quality of programs for young children. Keynote addressed at the International Conference of the World Organization for Early Childhood Education (4th, Hong Kong, March, 20-21, 1999).

Kaiser, M., \& Bauer, J. M. (2017). Preschool child care and child well-being in Germany: Does the migrant experience differ?. Social Indicators Research, 144, 1367-1390. https://doi.org/10.1007/s11205-019-02064-5

Kalous, J. \& Veselý, A. (2006). Vybrané problémy vzdělávací politiky. Praha: Karolinum.

Knudsen, E. J. (2006). Economic, neurobiological and behavioral perspectives on building America's future workforce. Proceedings of the National Academy of Sciences of the United States of America, 103(27), 10 155-10 162.

Krnjaja, Ž., \& Pavlović Breneselović, D. (2013). Where does the quality live. Policies of building early childhood quality. Belgrade: Institute for Pedagogy and Andragogy, Faculty of Philosophy, University of Belgrade.

Krnjaja, Ž. (2015). The Quality of Early Childhood Education Curriculum Framework in the Republic of Serbia. Bulgarian Comparative Education Society, Paper Presented At The Annual International Conference of The Bulgarian Comparative Education Society, 13(13),

191-197. https://files.eric.ed.gov/fulltext/ED568653.pdf

Lewis, K., \& Burd-Sharps, S. (2011). The measure of America 2010-2011. Mapping risks and resilience. New York and London: New York University Press. 
Malovic, M., \& Malovic, S. (2017). Parents' Perspective on the quality of kindergarten. Research In Pedagogy, 7(2), 200-220. https://files.eric.ed.gov/fulltext/EJ1165891.pdf

Majerčíková, J. (2019). Výsledky dotazníkového šetření s rodiči UMŠ QOČNA. Spokojenost rodičů s UMŠ Qočna. Nepublikovaný materiál.

Masse, L., Barnett S., \& Steven, B. (2002). A benefit cost analysis of the Abecederian Early Childhood Intervention. Philadelphia: Pew Charitable Trust. https://files.eric.ed.gov/fulltext/ED479989.pdf

Melhuish, E. (2001). The quest for quality in early day care and preschool experience continues. International Journal of Behavioral Development, 25(1), $1-6$.

Melhuish, E., K. Ereky-Stevens, K. Petrogiannis, A. Ariescu, E. Penderi, A. Rentzou, A. Tawell, P. Slot, M. Broekhuizen, \& P. Leseman. (2015). Care Curriculum Quality Analysis and Impact Review of European Early Childhood Education and Care (ECEC). A Review of Research on the Effects of Early Childhood Education and Care (ECEC) upon Child Development.' ECEC-CARE. https://www.researchgate.net/publication/291970194_A_review_of_researc h_on_the_effects_of_early_childhood_Education_and_Care_ECEC_upon_child_d evelopment_CARE_project

Navarro-Cruz, G., \& Luschei, T. (2020). Quality Preschool as Defined by Latina Mothers: A Qualitative Study Using a Funds of Knowledge Framework. Journal of Research In Childhood Education, 34(1), 6-27. https://eric.ed.gov/?q=preschool+quality\&id=EJ1239888

OECD (2018). Engaging Young Children: Lessons from Research about Quality in Early Childhood Education and Care. Paris: OECD Publishing. https://www.oecd.org/education/engaging-young-children-

9789264085145-en.htm

Pianta, R. C., Howes, C., Burchinal, M., Bryant, D., Clifford, R., Early, D., \& Barbarin, O. (2005). Features of pre-kindergarten programs, clasrooms, and teachers: Do they predict observed clasroom quality and child-teacher interactions? Applied $\begin{array}{lllll}\text { Developmental } & \text { Science, } & 9 & \text { 9(3), } & 144\end{array}$ https://doi.org/10.1207/s1532480xads0903_2

Pianta, R. C., Barnett, W. S., Burchinal, M., \& Thornburg, K. R. (2009). The effects of preschool education: What we know, how public policy is or is not aligned with the evidence base, and what we need to know. Psychological Science in the Public Interest, Supplement, 10(2), 49-88. Available on: http://doi.org/10.1177/1529100610381908

Průcha, J. (1996). Pedagogická evaluace: hodnocení vzdělávacích programů, procesů a výsledků. Brno: Masarykova univerzita.

Průcha, J., Walterová, E., \& Mareš, J. (2009). Pedagogický slovník. Praha: Portál. 
Rabušicová, M., Čiháček, V., Šed’ová, K., \& Trnková, K. (2004). Škola a (versus) rodina. Brno: Masarykova univerzita v Brně.

Rentzou, K., \& Sakellariou, M. (2013). Research's and parents' perspectives on quality of care and education. Early Child Development And Care, 183(2). https://www.researchgate.net/publication/254228414_Researcher's_and_pa rents'_perspectives_on_quality_of_care_and_education

Rosenthal, R., \& Vandell, L. D. (2008). Quality of Care at School-Aged Child-Care Programs: Regulatable Features, Observed Experiences, Child Perspectives, and Parent Perspectives. Child Development 67(5), 2434-2445.

Sevinç, M. (2006). Expectations of the mothers of children taking pre-school education. The Journal of Kazım Karabekir Faculty of Education, 13(1), 218-225.

Slot, P., Leseman, P., Verhagen, J. \& Mulder, H. (2015). Associations between structural quality aspects and process quality in Dutch early childhood education and care settings. Early Childhood Research Quarterly, 33, 64 - 76.

Slot, P. (2017). Literature review on Early Childhood Education and Care quality: Relations between structural characteristics at different levels and process quality. Paris: OECD.

Spilková, V. (2005). Proměny primárního vzdělávání. Praha: Portál.

Strategie vzdělávací politiky ČR do roku 2020. (2014). Praha: MŠMT.

Sylva, K., Melhuish, E., Sammons, P., Siraj, I. \& Taggart, B. (2014). Students Educational and Developmental Outcomes at Age 16: Effective Pre-School, Primary and Secondary Education (EPPSE 3-16) Project.' London: Institute of Education and Department for Education. https://www.gov.uk/government/uploads/system/uploads/attachment_dat a/file/351496/RR354_-

_Students_educational_and_developmental_outcomes_at_age_16.pdf

Sylva, K., Siraj-Blatchford, I., Taggart, B., Sammons, P., Melhuish, E., Elliot, K., \& Totsika, V. (2006). Capturing quality in early childhood through environmental rating scales. Early Childhood Research Quarterly,21(1), 76 -92. http://193.61.4.225/web-files/our-staff/academic/edwardmelhuish/documents/Sylva_et_al-2006-Capturing\%20quality_ECRQ.pdf Šteflová, J. (2011). Co znamená pro ředitele pojem kvalita školy. Učitelské noviny 2011(2425). Retrieved from: http://www.ucitelskenoviny.cz/?archiv\&clanek=6058

Litjens, I., \& Taguma M. (2010). Revised literature overviewfor the 7th meeting for the network on early childhood education and care. Paris: OECD.

OECD (2019). Providing Quality Early Childhood Education and Care. Retrieved from: $\quad$ https://www.oecd-ilibrary.org/docserver/301005d1en.pdf?expires $=1594809603 \& i d=i d \& a c c n a m e=$ guest\&checksum=92C1D36D6 0FC71691EE08BBF5D3F4C9C 
Tawil, S., Akkari, A., \& Macedo, B. (2012). Beyond the conceptual maze: the notion of quality in education. UNESCO. https://unesdoc.unesco.org/ark:/48223/pf0000217519

Ugaste, A., Tuul, M., Niglas, K., \& Neudorf, E. (2013). Estonian Preschool Teachers' Views on Learning in Preschool. Early Child Development and Care, 184, 370385.

Vašt'atková, J. (2006). Úvod do autoevaluace školy. Olomouc: PedF UP.

Woodhead, M. (1998). Quality in early childhood programmes - a contextually appropriate approach. International Journal of Early Years Education, 6(1), 517. In Rentzou, K., \& Sakellariou, M. (2013). Research's and parents' perspectives on quality of care and education. Early Child Development And Care, 183(2).

https://www.researchgate.net/publication/254228414_Researcher's_and_pa rents'_perspectives_on_quality_of_care_and_education

Workman, S. \& Ullrich R. (2017). Quality 101: Identifying the Core Components of a High-Quality Early Childhood Program. USA: Center for American Progress. Retrieved from: https://www.americanprogress.org/issues/earlychildhood/reports/2017/02/13/414939/quality-101-identifying-the-corecomponents-of-a-high-quality-early-childhood-program/\#fn-414939-2

Whitaker, J. (2017). What parents expect from schools? Parenthub. Retrieved from https://www.parenthub.co.uk/what-do-parents-expect-from-schools/

\section{Acknowledgments}

This article originated with the support of the IGA/FHS/2020/002 project titled The attitudes of parents towards pre-school education under the conditions of the Czech and Slovak Republics, researched at the Faculty of Humanities at Tomas Bata University in Zlín.

\section{Contacts}

doc. PaedDr. Jana Majerčíková, Ph.D.

Mgr. Beata Horníčková

Faculty of Humanities at Tomas Bata University in Zlín

Štefánikova 5670

67001 Zlín

Czech Republic

majercikova@utb.cz

b_hornickova@utb.cz 